\title{
THINKING ABOUT CERTAINTY AND TOLERANCE WITH MICHEL EYQUEM DE MONTAIGNE
}

\begin{abstract}
Michel Montaigne's thinking, though primarily relevant to and based upon his own historical context, exhibits unique traits and provides inspiration to current socio-political, ethical, and philosophical discourse. This study deals with Montaigne's peculiar epistemological skepticism, arguing that, if adequately understood, it may prove an important factor in human striving for tolerance. With his emphasis on the emancipation (and separation) of politics from religion and positing the will of an individual human person as the determining factor in the development of human societies, Montaigne brings a significant contribution.
\end{abstract}

Keywords: Michel Montaigne, skepticism, tolerance, epistemology, certainty.

\section{Introduction}

The legacy of Michel de Montaigne (1533-1592), an important French intellectual from the 16th century, should be considered in the historical context of his life and, even more importantly, within the wider historical framework of late-medieval Europe. [1,2 and 3] As a continent as well as a civilization, Europe was undergoing significant political, economic, military, as well as cultural changes in the 16th century. Montaigne dies exactly 100 years after the discovery of the "New World". European nations such as England, Portugal, Spain (etc.) are stretching their muscles while expanding the horizons of their influence. Murderous raids of the Spanish conquistadors are contrasted by pious heroism of great religious figures like St. Ignatius of Loyola, St. Francis Xavier, Theresa of Avila, St. John of the Cross (among others). Nicolaus Copernicus publishes his groundbreaking work De revolutionibus orbium coelestium in 1543 and the German reformers manage to bring the mightiest ruler in Europe to sign the Peace Treaty of Augsburg in 1555, though only after ruthless religious fighting and mutual persecution among Protestants and Catholics throughout Charles V. German speaking domain and beyond [4, p. 213-215]. The Catholic reform is successfully launched at the Council of Trent in 1545 (the concluding session in 1563), marking the beginning of the Catholic counterreformation movement that would claim many lives and result in the greatest war that Europe was to experience up until then (the 30-Year War, 1618-1648). The Battle of Lepant (1571) stopped the seemingly unstoppable Turkish invasion into the Mediterranean, while the Sultan Suleiman II launched his mighty campaign against the Southern and Eastern provinces of Hungary and the Balkan countries.

Events like these bring Europe to a new epoch. Old securities are waning and new ones, though tantalizing, are unproved and uncertain. The situation, on the one hand, calls for a simple order, a clear system that would order the lives of individuals and societies and rid it of excessive privileges, while at the same time promoting individual freedom and responsibility; on the other hand, a robust continental struggle is picking up its pace in which individual countries and principalities are drawn into an unavoidable confrontation of the existing hierarchical system with the emerging world of individualism and rationalism [5, p. 197], culminating in the subsequent rise of science, industry and trade. Modern age, though not yet fully born, knocks at the gates of the passing age, promoting the ideology of rejecting the things of the old world. Moral relativism creeps in, expressing itself in the rising reception of epicureism and stoicism, which only further helps emphasizing the individual disposition of a human person to freely make decisions regarding the matters of one's life [6]. In France, the policy of the state is to centralize power in order to face the alliance of its Spanish rival with the Papal State in Italy. The internal social and political changes result in the devastating civil war of 1562-1598 [7]. Michel de Montaigne lives in these volatile times. With his emphasis on the emancipation (and separation) of politics from religion and positing the will

\footnotetext{
* ${ }^{1}$ Cyril Diatka, ${ }^{2}$ Jan Ligus

${ }^{1}$ University of Constantine the Philosopher, Faculty of Arts, Nitra, Slovakia

${ }^{2}$ Hussite Theological Faculty, Charles University in Prague, Czech Republic

E-mail: cdiatka@ukf.sk
} 
of an individual human person as the determining factor in the development of human societies [8, p. 137-138], Montaigne brings a significant contribution [9].

\section{Historical Self-awareness as Condition for Free Action}

Michel de Montaigne shares the criticism of the old order and the energy to think for himself with other important figures of his century (such as Martin Luther) but he turns out to be an intellectual of his own (new) sort. One of his main principles is his conviction that understanding one's own life (as historically situated) is a necessary precondition for free decision-making and action.

Suffice it to say, in the limited space of this current study, Michel de Montaigne was well aware of the role that his own upbringing came to play on his values and character formation. He came from an aristocratic family where his father, Pierre Eyquem de Montaigne, was a provincial judge (in Bordeaux) and his mother, Antoinette de Luppes, a member of a wealthy, Jewish Portugal family. His own parents, thus, embodied not only a rich diversity of family origins and outlooks on life but also a live example of tolerance and mutual understanding. In addition to this, Michel's father was a hardworking, well-read, and innerly disciplined man with a profound effect on his son. His inclination to the values of moral pathos of the Renaissance Stoicism, promoted by the efforts of humanist intellectuals of the time, had its roots in the Platonic body-soul dualism. Pierre de Montaigne thus came to the conclusion that human being is a self-aware, personal being with a clear inner drive for self-realization. As such, human being is responsible to God (understood in a more or less deistic sense). Michel de Montaigne's father was, therefore, convinced that his son must be thoroughly educated from his early childhood, including the study of music, arts and literature, and, above all, proper philosophy, exercised not only intellectually but also existentially in the sense of making concrete decisions and taking responsibility for them.

Michel de Montaigne's study of classical ancient philosophy started early on and continued throughout his life. By placing emphasis on his own, subjective deliberation, however, Montaigne invented a new "rhetorical system" for re-structuring and re-interpreting numerous classic philosophical ideas in a modern fashion: "If being a philosopher means being insensitive to human frailties and to the evils or to the pleasures which befall us, then Montaigne is not a philosopher. If it means using a "jargon", and being able to enter the world of scholars, then Montaigne is not one either. Yet, if being a philosopher is being able to judge properly in any circumstances of life, then the Essays are the exemplary testimony of an author who wanted to be a philosopher for good. Montaigne is putting his judgment to trial on whatever subject, in order not only to get to know its value, but also to form and strengthen it.” [10, http://plato.stanford.edu/entries/ montaigne/\#Con].

"Get to know yourself" [11, p. 153] and "get to know the world" [11, p. 218] - these continued to be the leading mottos of Michel's education at home and beyond. Already at the age of 13, young Montaigne begins to contemplate the intricacy of relationships between humans and nature and the ambiguity of dimensions of life and death. His contemplative, thoughtful nature comes into conflict with his strict upbringing at this juncture. Instead of disciplined memorization, Montaigne came to promote independent reflection and creative thinking [12]. The power of "nature" (e.g., natural curiosity), according to Montaigne, should be allowed to play its part, unhampered by human devices (this approach might place Montaigne in the position of a forerunner to J.J. Rousseau and a precursor to L.N. Tolstoj, in a certain sense). He shocks his contemporaries with statements like: "I have, as I have said elsewhere, quite simply and crudely adopted for my own use the ancient rule that we cannot go wrong in following nature, and that the sovereign precept is to conform to her. I have not, like Socrates, corrected my natural disposition by force of reason, nor used any art to interfere with my native inclinations;" [11, p. 338] and then he adds: "May I say this in passing, that I find we attach more value than it deserves to a certain idea of scholarly integrity, almost the only one in vogue amongst us, which makes learning a slave to precept and fetters it with hope and fear? I would have it not formed, but perfected and justified, by laws and religions, conscious of being able to sustain itself without help, springing up within us with its own roots from a seed of universal reason, which is implanted in every man who is not corrupt by nature." [11, p. 339] Instead of pedantic memorization, thus, learners should be encouraged to, so to speak, create their own being/personhood face to face to the fullness of the world [13]. Such creative freedom enables one to form their own attitudes, inner dispositions, and value judgements about the outer reality as well as one's own relationship to the outer world. Montaigne embodies this ideal in his own creative approach. In his magnum opus work - Essays - "Montaigne shows himself to be programmatically unphilosophical. He sets out to write not impersonally but personally, not comprehensively but partially and inconsistently, not supra-temporally but consciously immersed in the passage of time; he relies on an unsystematic mixture of anecdote, quotation, and moral reflection, into which in the course of the last twelve years of his life he interpolated intermittently yet more thoughts and quotations; his text rarely takes on the character of a sustained argument that is explicit about its own forms of validation" [14, p. 143-144].

Young Montaigne was not excited about most of the contents of his study at Colege de Gyuenne, preferring rather the study of Roman classics, especially Ovidius and, later on, the philosophical school of Skepticism. In his adult life, Montaigne got his share of administrative (as counselor in Bordeaux Parliament) and political duties (as the mayor of Bordeaux and royal counselor). His political career, however, did not bring much satisfaction 
to thoughtful and contemplative Montaigne. Thus, having the means to lead a comfortable life at his mansion in Montaigne (about $45 \mathrm{~km}$ east of Bordeaux), he decided to step down from his political and administrative duties and live a relatively secluded life, being fully devoted to philosophy and writing. He collected his ideas into his famous Essays - "Essais de Messier de Michel Seigneur de Montaigne. Livre et premier et de second" (Bordeaux 1580) [15]. However, at the height of civil war, Montaigne decided to try to mediate between the fighting camps of Protestant Huguenots and the Catholic League. He traveled personally to Paris in 1588 but his efforts only led to his imprisonment in the hated Bastille prison. However, with the rise of Henry IV. as king of France in 1589, Montaigne was not only vindicated but offered a high position at the royal court. Due to his deteriorating health, Montaigne politely rejected the offer and spent the rest of his days in his mansion, where he died on September 13, 1592.

\section{Hopeful Skepticism as a Way to Epistemological Sobriety}

Montaigne is intellectually provoked by a peculiar type of ignorance on the side of humans regarding life and its meaning. His way of dealing with this situation is to free human innermost beliefs and convictions from the authorities of this world (especially those of the church). He then attempts to lead the human subject to a conjunction of a transformed faith - i.e. faith ridden of institutional ideologies and morphed into an intense, personal experience - and of free, emancipated, though necessarily incomplete knowledge. This subjective experience of faith in the sense of emancipated self-knowledge may serve as a certain satisfaction vis-à-vis one's realization of one's own contingency and limitedness. Everything in nature, all living things, are bound to die. The ensuing sense of meaninglessness and/or nihilism can be countered by one's self-knowledge and selfrealization. To know oneself is thus an ever emerging and growing theme in Michele de Montaigne's intellectual reflection, placing him among thinkers such as Heraclitus, Socrates, Chrisyppos, Epictetus, Abelard, Dante, Petrarca, Erasmus of Rotterdam, etc.

Montaigne recognized human natural need for knowledge, the source of which were primarily reason and experience. He did not connect these directly with faith and religious sensitivity, for the spheres of religion and knowledge must be, according to Montaigne, strictly separated [11, p. 309, 314, etc.]. For, as Montaigne exclaims, using Livy's words: "Nothing has a more deceptive face than a corrupt religion, in which the divine will acts as a screen for crimes"; [11, p. 319] and a few pages later he states: "It is a doctrine ruinous to every society, and far more harmful than clever or subtle, which persuades people that religious belief alone, without morality, is sufficient to satisfy divine justice. Practice shows us an enormous difference between piety and conscience" [11, p. 339]. is human frailty and finitude. Our senses are not fully reliable and do not convey the certainty one wishes for. Thus Montaigne soberly realizes that "As for the natural faculties within me, of which my writing is the proof, I feel them bending under the burden. My ideas and my judgement merely grope their way forward, faltering, tripping, and stumbling; and when I have advanced as far as I can, I am still not at all satisfied. I can see more country ahead, but with so disturbed and clouded a vision that I can distinguish nothing” [11, p. 50]. Our attempts to prove their validity by our reason only lead us from one argument to another in an infinite progression of proofs - which, ultimately, leads nowhere.

The ensuing epistemological humility is explicated by Montaigne in one of his longest essays titled "Apology of Raymund de Sabonde" (originally intended as a separate work). In it he offers a sharp criticism of human cognitive abilities. When we focus on our knowledge of nature, for example, we are confronted with a labyrinth of conflicting ideas and experiences. Thus, neither in natural philosophy, nor in the intimate knowledge of one's soul is there a fully true knowledge. The world is full of blabber of various untruths, philosophical absurdities, and sophistry. The human subject is entangled in human traditions and bound by his blind faith in authorities (such as Aristotle, or the authority of ecclesiastical offices). His true essence and capacities remain hidden. Neither can we find certainty in moral laws, since that which is valid and binding in one country may not be valid in another. That, which is lifted up as ideal in one historical and geographic context, may be considered a vice in another. Humans are not able to understand with certainty the general laws of the world (including moral conduct). One may say, in a sense that the world is a heap of disordered realities, full of confusion and paradoxes.

The sobering recognition of this fact may lead us to a humbler approach to learning about and interacting with other people and the world. This epistemological uncertainty may open us up to a more diverse approach, to a willingness to look at things from different angles. This is why Montaigne "distrusts universal statements, and seems enamored of the exception, of the particular case... We move from a general rule to an exception, then to an exception to the exception, until we seem to be left hanging. The impression of open-endedness that many chapters of the Essays convey is linked to the author's willingness to indulge any sort of particular case" [16, p. 1]. The goal of Montaigne's skepticism "is not to ruin arguments by opposing them, as it is the case in the Pyrrhonian 'antilogy', but rather to counterbalance a single opinion by taking into account other opinions" [10, http://plato. stanford.edu/entries/montaigne/\#MonSce] Only when humans grasp the fact that they are finite and fallible, that their ability to know is limited at best and prejudiced at worst, can they alter their behavioral patterns in relation to other (i.e. different) people.

Truly inspiring are Montaigne's views on the position of morality in the social dimension. Having lived through times of 
abrupt changes and horrifying cruelties in $16^{\text {th }}$ century France, he comes to the conclusion that social life with its rules and customs, needs and interests, cannot be the true, genuine foundation of virtues. The wellbeing of French society (which, in itself, is difficult to define), understood as the ultimate goal of social interactions, is often being pursued by illegitimate, or inadequate means, including treachery, torture, and murder. From this follows, according to Montaigne, that "social usefulness" must be clearly distinguished from "virtue". Virtue and social usefulness (a form of utilitarianism) part ways at the moment when necessary acts mutate into recklessly ambitious plans. Though Montaigne is no idealist, he does maintain that, under certain conditions, one must always act in accordance with virtue, even if it meant sacrificing one's wellbeing (or social wellbeing) in the anticipation that God's gracious providence will not refuse to support the just and pure action of humans. Since humans are not almighty, they must often hand over the navigation of their "ship" to God, seeing in Him the anchor of safety. In a similar fashion to that of Kant, though not discursively but rather intuitively, Montaigne moves in solving this issue to a position of expectation, to anticipating God's gracious, providential care. Among other things, this also implies that any reward of virtuous actions should not be expected in this historical reality but that one should rather rely on God's providence as it plays out in a future state of things.

We might, in a way, sense an anticipation of the stance that we later see in Blaise Pascal and, centuries later, in Soren Kierkegaard [17]. In contrast to that, we see a dramatically different approach in Rene Descartes who defines morality as the freedom of will to do that which human reason presents to us as our comprehension of the truth and the good. The capacity of our reason to determine/discern that which is true and good then implies that genuine understanding is identical with virtue. Montaigne, in fact, made it a point of his philosophic endeavor to show that such identification is not only intellectually illegitimate but also socially dangerous. "Not only does Montaigne criticize philosophers for their inattentiveness to their own humanity, but he intentionally fashions his own writings to be unlike philosophy" [16, p. 1].

\section{Towards a New Foundation for Tolerance}

Montaigne concludes his contemplation of virtue with the following points that carry promising potential for establishing a new foundation for tolerance in society [18]. One should respect one's historical context. Humans should abide by the given order, instituted in a particular country (where these humans are historically situated) - so there is room for civic obedience - but the society must not interfere in personal opinions of individuals - which is a clear reference to the freedom of conscience [19]. Montaigne promotes the principle of cultivating benevolence to others with different opinions. This we can achieve by an intentional effort on our part to understand the position of the "other", trying to view the disputed matter from his point of view (through his eyes). We should not succumb to the temptation of comparing others with us, employing our standards of measurement, but we ought instead to consider them in their own context, how they measure up to their own standards of conduct. Montaigne articulates his conviction in this respect on several places of his Essays with vigor and resolve: "Everyone thinks himself the master pattern of human nature; and by this, as on a touchstone, he tests all others. Behavior that does not square with his is false and artificial. What brutish stupidity! For my part, I consider some men, particularly among the ancients, greatly superior to me; and though I clearly recognize my inability to follow in their footsteps, still I follow them with my eyes, and observe the force that lifts them so high" [11, p. 232]. Even if we do not adopt the customs and expressions of other cultures, we can still be free to see positive aspects in them and to show our respect (3). It is not enough if we flee from other people; we must flee from the attributes of the crowd which sends its roots deep into our inner selves. One must part with oneself, only in order to find oneself again. We should not cling to our accrued status or wealth. Instead, we should vigorously practice self-control, [20] which happens to be the most important thing in the world.

Montaigne is offering his society a bold new outlook on the goals and meaning of life. The aim of human life should be subordinated to the human individual, not some external values that are anchored in transcendence. Each human life has its own rich resources and is thus, in a sense, self-consistent and selfsufficient. Human individual is sovereign to himself, though each individual bears the image of the whole human plight. From this follows that each person should love all people, trust only a few, and harm no one.

\section{Conclusion}

Montaigne understood skepticism as an ethics of judgement rather than as vicious tool to defeat enemies or a self-negating tool that leads to oblivion. The path to a mature, personal judgement leads through a thoughtful, intentional absorption and mental processing of personal experience, wider historical circumstances, and (yes, this too!) doctrines and dogmas. "[T] he development of character integrity must remember the organic nature of moral experience" [21, p. 107] Montaigne's hopeful skepticism demolishes absolute certainty only to reinstitute what we might label "viable probability" - that what seems (often intuitively) right and true to us. This, however, is nothing like modern individualism, or absolute subjectivism. We are dealing here with an informed judgement of a qualified subjectivism, i.e. subjectivism shaped by one's intentional struggle to understand oneself as a product of as well as a critic of one's circumstances. Human thought is and should always be perceived as dialogic in 
nature. Instead of arriving at absolute truth and then defending and promoting it, often at the expense of those disagreeing with us, we should keep the dialogue going because none of us can claim an absolute perspective [22]. This stimulates a new disposition of the human heart, a new outlook of tolerance. It also helps us preserve a genuine freedom: if we don't have to find and defend absolute truth, we are free to disagree; we are free to fail to comprehend completely; we are free to accept the fact that someone might know more and we might learn from them. As Stefan Zweig said: "Montaigne helps us answer this one question: 'How to stay free? How to preserve our inborn clear-mindedness in front of all the threats and dangers of fanaticism, how to preserve the humanity of our hearts among the upsurge of bestiality?"' $[10$, http://plato.stanford.edu/entries/montaigne/\#Con].

Lest this line of reasoning lead us to hopeless relativism, on the other hand, Montaigne emphasizes personal responsibility of every human individual to make mature judgements in order to arrive at the most convincing conclusion that is possible. One should do it by examining and weighing the strengths and weakness of all conceivable positions, patiently listening to arguments of others, even being willing to place oneself in other's "shoes" in attempt to see the world through their eyes. Personal experience of a lifetime is at our disposal and our task is to actively process it. What awaits us at the end is a "joyful wisdom" - the fruit of our humility, openness, perseverance, and ever-present doubt. The loss of epistemic certainty may ultimately yield true wisdom of life. In this sense, Montaigne brought philosophy to its original starting point - to the sense of awe that keeps a philosopher curious and humble at the same time. Thus we may agree that " $[\mathrm{t}]$ he path to an authentic subjectivity seems to lead inevitably through the complicated and sometimes painful struggles of life. One should not expect to make sense of his own life without an arduous struggle to interpret one's existence in relation to self, the world, and to God" [21, p. 106].

\section{References}

[1] HEN, J.: I, Michel de Montaigne (in Czech), Praha : Odeon, 1990.

[2] MARCI, L.: Autonomy of Personality and the Problem of Power in the Views of N. Macchiavelli and Michel de Montaigne (in Slovak), Nitra : Univerzita Konstantina Filozofa, 1999.

[3] SVITAK, I.: Montaigne, Praha : Orbis, 1966.

[4] VALCO, M.: Setting the Stage for a Meaningful Engagement: The Need for a Competent Public Theology in the Post-Communist Context of Slovakia. In: M. Valco \& D. Slivka (eds.), Christian churches in post-communist Slovakia: current challenges and opportunities, Salem, Virginia, Center for religion and society, Roanoke college, 2012, 185-256. "Confiscated church buildings and schools, forced labor in mines, torture, extortion, discrimination in the religious, political, social, as well as academic sense - all these belonged to the harsh reality of those times" (p. 213).

[5] We need to pay more attention to "how the ideas and methods of the Enlightenment" (p. 197) influenced the religious, social, and political thinking of not only Montaigne's era but how they continue to influence our own paradigms. See: VALCO, M.: Alternative viewpoint: Edwards and the world religions. McDermott, G. (ed.). Understanding Jonathan Edwards: An introduction to America's theologian. Oxford : Oxford University Press, 2009, pp. 195-200.

[6] TRETERA, I.: Historical Outline of European Thinking (in Czech), Praha : Litomysl : Paseka, 1999.

[7] MAUROIS, A.: History of France (in Czech), Praha : NLN, 1994.

[8] With regard to this topic, one might consider Montaigne a precursor to certain elements in the existential thinking of S. Kierkegaard. A mature, self-aware, responsible individual is by both considered as the foundational building block of a healthy society. See: VALCO, M.: Rethinking the role of Kierkegaard's authentic individual in liberal capitalist democracies today. European J. of Science and Theology, vol. 11, No. 5 (2015), 129-139. ISSN 1841-0464. "Kierkegaard's calling the human self to what we may call a 'relational authenticity' may constitute the much needed inception (or inculcation) that will then grow to fuller complexity and beauty of transformed individuals and societies." (Ibid., p. 137); VALCOVA, K., PAVLIKOVA, M., ROUBALOVA, M.: Religious Existentialism as a Countermeasure to Moralistic Therapeutic Deism, Communications - Scientific Letters of the University of Zilina, vol. 18, No. 3, 2016, 98-104.

[9] Gregory, M. E. conducted an incisive study on the nature and capacity of the human will according to Michel de Montaigne (as compared with other selected thinkers), placing him in the "soft determinism" camp along with David Hume, Baruch Spinoza, Thomas Hobbes, John Locke, Jean-Jacques Rousseau, François-Marie Arouet de Voltaire, G.E. Moore, A.J. Ayer and Harry G., Frankfurt. See: GREGORY, M. E.: Free will in Montaigne, Pascal, Diderot, Rousseau, Voltaire and Sartre, New York : Peter Lang, 2012, 9.

[10] FOGLIA, M.: Michel de Montaigne, in The Stanford Encyclopedia of Philosophy (Spring 2014 Edition), Edward N. Zalta (ed.), URL $=\langle$ http://plato.stanford.edu/archives/spr2014/entries/montaigne/>. [cit. Feb 05, 2016]

[11] DE MONTAigne, M.: Essays, J. M. Cohen (transl. and ed.), London : Penguin, 1993.

[12] DE MONTAIGNE, M.: Principles of Upbringing (in Czech), Valaske Mezirici : Fr. Vanek, 1886. 
[13] For a recent inspiring study on how to holistically integrate creative freedom and intrapersonal responsibility in current educational contexts, see: CABANOVA, V.: Social Attitudes and Values of Young People in the Context of Multicultural Education. Communications - Scientific Letters of the University of Zilina, vol. 16, No. 3, 2014, 4-8. ISSN 1335-4205.

[14] MACLEAN, I.: Montaigne and the Truth of the Schools, in U. Langer (ed.), The Cambridge Companion to Montaigne : Cambridge : Cambridge University Press, 2005, 142-162.

[15] Here it is worth mentioning that Montaigne's Essays were placed on the Index of prohibited books (Index Librorum Prohibitorum) by the Papal Office in Vatican in 1676.

[16] LANGER, U.: Introduction, in U. Langer (ed.), The Cambridge Companion to Montaigne : Cambridge : Cambridge University Press, 2005, 1-8.

[17] "For Kierkegaard, truth is more than a noetic, objective category, accessible to intellectual inquiry by a thinking subject. There must be a deeper, existential basis, related to the deepest aspirations and, yes, fears and doubts of the individual - a desire permeated by passion. The truth cannot be meaningful and relevant without this ,subjective desire,' whose doubt is the beginning of the highest form of existence”, (p. 27), VALCO, M. \& VALCOVA, K.: The epistemological challenge of Kierkegaard's truth is subjectivity principle, Communications - Scientific Letters of the University of Zilina, vol. 16, No. 3, 2014, 25-28. ISSN 1335-4205. For recent studies on Kierkegaard's thought in our geographic provenience, see also: VALCO, M.: Kierkegaard's 'Sickness unto death' as a resource in our search for personal authenticity, European J. of Science and Theology, vol. 12, No. 1, 2016, 97-105. ISSN 1841-0464; KRALIK, R.: Kierkegaard and his influence on Tillich's philosophy of religion, European J. of Science and Theology, vol. 11, No. 3, 2015, 183-189. ISSN 1841-0464; KONDRLA, P. \& KRALIK, R.: The Specifics of Mission of the Thessalonian Brothers and the Potential for their Actualization (in Slovak), Konstantinove listy, vol. 9. No. 2, 2016, 90-98, ISSN 1337-8740; KONDRLA, P. \& PAVLIKOVA, M.: From formal ethics to existential ethics, European J. of Science and Theology, vol. 12, No. 3, 2016, $101-111$. ISSN 1841-0464; KONDRLA, P. \& KRALIK, R.: Authentic being and moral conscience, European J. of Science and Theology, vol. 12, No. 4, 2016, 155-164. ISSN 1841-0464; KRALIK, R. \& TOROK, L.: The "Moment" Kierkegaard's attack upon christendom, European J. of Science and Theology, vol. 12, No. 3, 2016, 45-53. ISSN 1841-0464; PAVLIKOVA, M.: The concept of anxiety and its reflection in Auden's work „the age of anxiety“, European J. of Science and Theology, vol. 12, No. 4, 2016, 111-119. ISSN 1841-0464; REPAR, P.: The Existential Dialectics of Decision and the Scandalon (in Slovak), Filozofia, vol. 67, No. 8, 2012, 689-704. ISSN 0046-385X, (etc.).

[18] Theological philosophy is also dealing with the relationship between human freedom and conscience and both concepts are also linked with responsibility. The theological ethics of Dietrich Bonhoeffer deals with the same issue in the first half of the 20th century, as it is explicitly shown in doctoral thesis of N. Bravena: "The two concepts: freedom and conscience are inextricably linked with responsibility", especially in certain human actions. It also means that "responsibility, which would force to act against human own conscience would condemn itself". See: BRAVENA, N.: Jesus Christ, a brother and a neighbor act in my place. Vicariousness in the theology of Dietrich Bonhoeffer (in Czech), Edice Pontes : Pragensis, vol. 56, Brno : L. Marek, 2010, p. 166. The relationship of conscience, freedom and responsibility closer illuminates Montaign's philosophy of life (for more details, see: CETL, J., HORAK, P. et al.: History of European Thought (in Czech), Praha : Panorama, 1984, p. 258-260.

[19] In his Essays, Montaigne is also interested in the importance of education for human life and society. His pedagogical principles correspond with his philosophy of life according to which "education does not only lead man to book learning and verbal knowledge, but understanding the nature of things that could humanly organize his life." CETL, J., HORAK, P. et al.: History of European Thought (in Czech), Praha : Panorama, 1984, p. 260. For proper education, therefore, it is very important recognize the "impact of teacher's personality on the development of natural talents and endowments and action of real-life people and books." (Ibid., p. 260). This was often forgotten and overlooked in education. Montaigne's emphasis on personal influence and example in education leads to appreciation of each individual person. Its intentional cultivation is highlighted by "the transcendent dimension of pedagogy" which emphasizes "the uniqueness of human You (Thou), its capabilities and ...it offers help for any individual neglect in upbringing." BRAVENA, N.: Do not be Preoccupied with Merely yourself ... Overlap and its Significance for the Socialization and Formation of a Child as Personality (in Czech), Praha : UK PedF, 2016, p. 159.

[20] "Montaigne's watchword, like Goethe's, is Restraint (Je m'abstiens), which he took from the Greek sceptics, and inscribed, in Greek, on the reverse side of his famous medal." COHEN, J. M.: Introduction, in Michel de Montaigne, Essays, J. M. Cohen (transl. and ed.), London : Penguin, 1993, 12.

[21] VALCO, M., KRALIK, R., BARRETT, L.: Moral Implications of Augustine's Philosophical and Spiritual Journey in his Confessions. Communications - Scientific Letters of the University of Zilina, vol. 17, No. 2, 2015, 103-108. ISSN 1335-4205.

[22] PETRO, M.: Human Being as a Person - Hope for Europe (in Slovak), P. Dancak (ed.), The Sapiential Character of John Paul II's Anthropology in the Context of the European Integration, Presov : University of Presov, 2006, 96-111. In his study, Petro argues that Europe's future depends on the consistent cultivation of a free dialogue of values, the starting point of which is the notion of intrinsic dignity of all humans.

Translated by Michal Valco. 